\title{
Histochemical Study of the Rat Anterior Pituitary LH-Gonadotroph after Administration of Luteinizing Hormone Releasing Hormone (LH-RH)
}

\author{
Tsuyoshi SojI \\ Department of Anatomy (Prof. M. Mryoshi), University of Fukuoka School of Medicine, Fukuoka, \\ Japan
}

Received October 29,1981

\begin{abstract}
Summary. The aim of this study was to identify the LH-gonadotroph, aided by histochemical demonstrations of adenylate cyclase and acid phosphatase activities in 60-day-old male rats, after a single $100 \mu \mathrm{g}$ injection of luteinizing hormone-releasing hormone (LH-RH). The results obtained are as follows: 1) Separation of the lysosomes from the large secretion granules in the LH-gonadotroph was accompolished in order to demonstrate acid phosphatase, the marker enzyme of lysosomes. 2) The large granules in the LH-gonadotroph decreased remarkably in number within 5 min after LH-RH injection. 3) A marked and prolonged increase in adenylate cyclase activity was observed on the plasma membrane of the LH-gonadotroph after LH-RH injection; this increase continued up to $30 \mathrm{~min}$. 4) At 60 min after LH-RH injection the small secretion granules began to decrease in number. 5) Losing the large granules due to the LH-RH treatment, the LH-gonadotroph resembled the FSH-gonadotroph.

From these observations it appears that the FSH-gonadotroph is an immature or storage state LH-gonadotroph and that it changes from an LH-gonadotroph into an FSH-gonadotroph on the loss of its large secretion granules.
\end{abstract}

Since Kurosumi (1968) and Kurosumi and Oota (1968) tried to identify the LH-gonadotrophs in pituitary cells, many similar efforts have been reported (RENNELs et al., 1971; Shino and Rennels, 1973; FARQUHAR et al., 1975; Herbert, 1975). With electron microscopicy, the LH-gonadotrophs have been morphologically described as having large $(700 \mathrm{~nm})$ secretion granules as well as small $(250 \mathrm{~nm})$ granules in the cytoplasm. The FSH-gonadotrophs, in contrast have only small secretion granules.

Using the slow infusion technique of the luteinizing hormone-releasing hormone (LH-RH), ARIMURA et al. (1972) observed elevations in LH as well as in FSH values in the serum. DeBeljuk et al. (1973) reported that the FSH-gonadotroph reacted to LH$\mathrm{RH}$ in an experimental autotransplant of the pituitary gland into the renal capsule of a hypophysectomized rat. Since NAKANE's development of electron microscopic immunohistochemistry (1970), it has been shown that both LH and FSH are produced in the same gonadotrophs (Mirecha and PeASE, 1971; Phifer et al., 1973; Robin et al., 1973; Toug ARD et al., 1973; HERBERT, 1975).

SoJi et al. (1974) found that a transitional type of cells between the LH and FSHgonadotrophs (gonadotroph III/IV) appeared after an intravenous injection of LH-RH, 


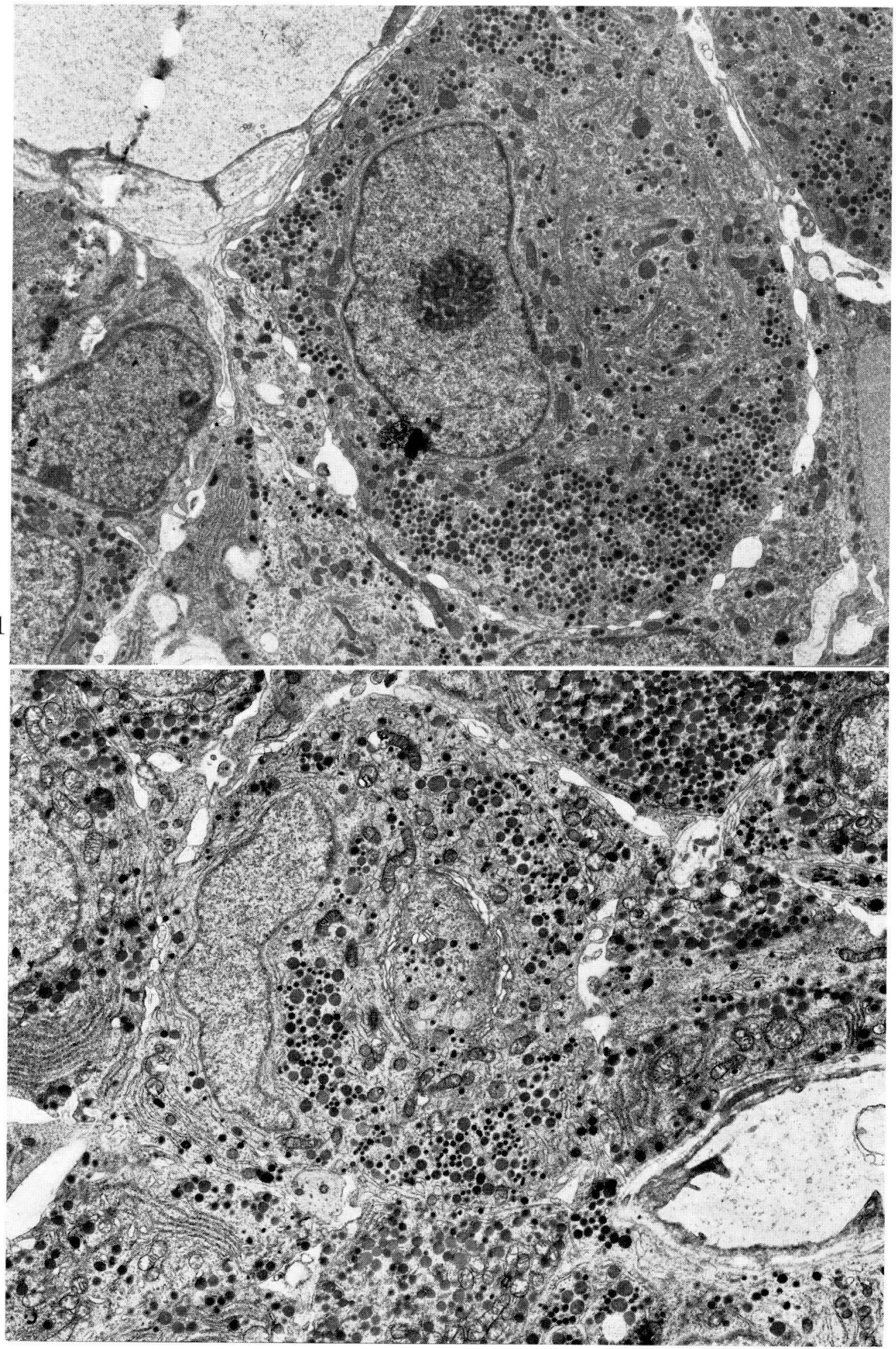

Fig. 1 and 2. Legends on the opposite page. 


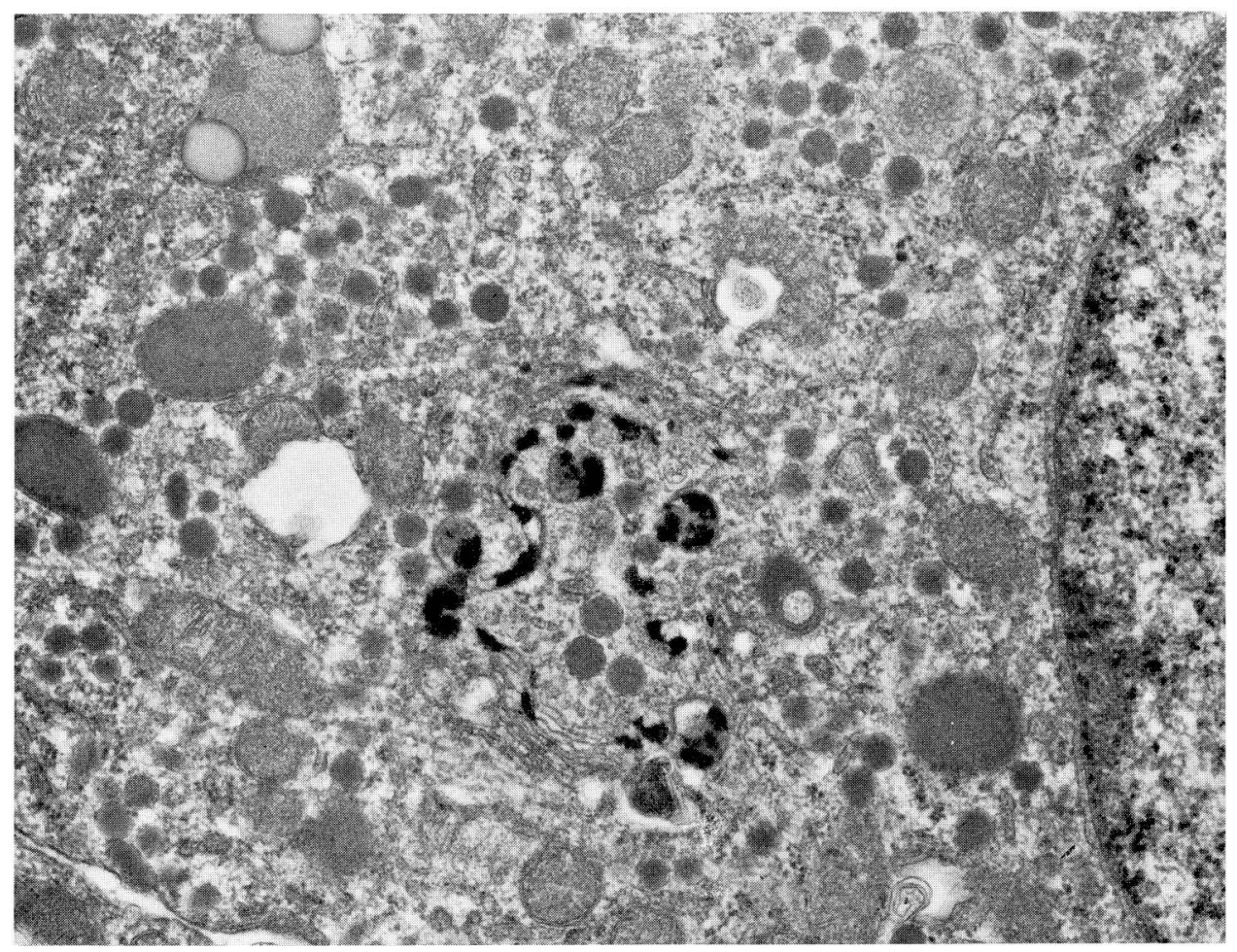

Fig. 3. Acid phosphatase activity in an LH-gonadotroph. The endproducts of lead phosphate are seen on the lysosomes and Golgi apparatuses. No reaction products are seen on the secretion granules. $\times 27,000$

whereby elevations in the LH and FSH concentrations in the serum were observed about 5 min after injection. Similar results were obtained by an experimental slow infusion of LH-RH and TRH (SoJI, 1978a, b).

Since biochemical studies have shown that adenylate cyclase plays an important role in LH-gonadotrophic secretions (LABRIE et al., 1975; Spona, 1975; Yoshida et al., 1976; BAUmAn and KunL, 1980), purposes here were made in this study to discover its precise localization as well as its changes after administration of LH-RH, with the results serving of clarification of the relationship between the LH-gonadotrophs and the FSH-gonadotrophs.

\section{MATERIALS AND METHODS}

Wistar-Imamichi male rats about 60-day-old were used. The experimental animals were intravenously given a single injection of $100 \mu \mathrm{g}$ of LH-RH while the controls were

Fig. 1. FSH-gonadotroph in the pituitary of a normal male rat. This cell type containing small type granules $(250 \mathrm{~nm})$ is charactrized by being a size larger than other cells. Cisterns of endoplasmic reticulum and well developed Golgi apparatuses are seen. $\times 6,800$

Fig. 2. LH-gonadotroph in a normal male rat. Both small and large type granules (250 and $700 \mathrm{~nm}$ ) are seen in the cytoplasm. The Golgi apparatuses are arranged in a circle. Acidophils are seen near the LH-gonadotroph. $\quad \times 6900$ 


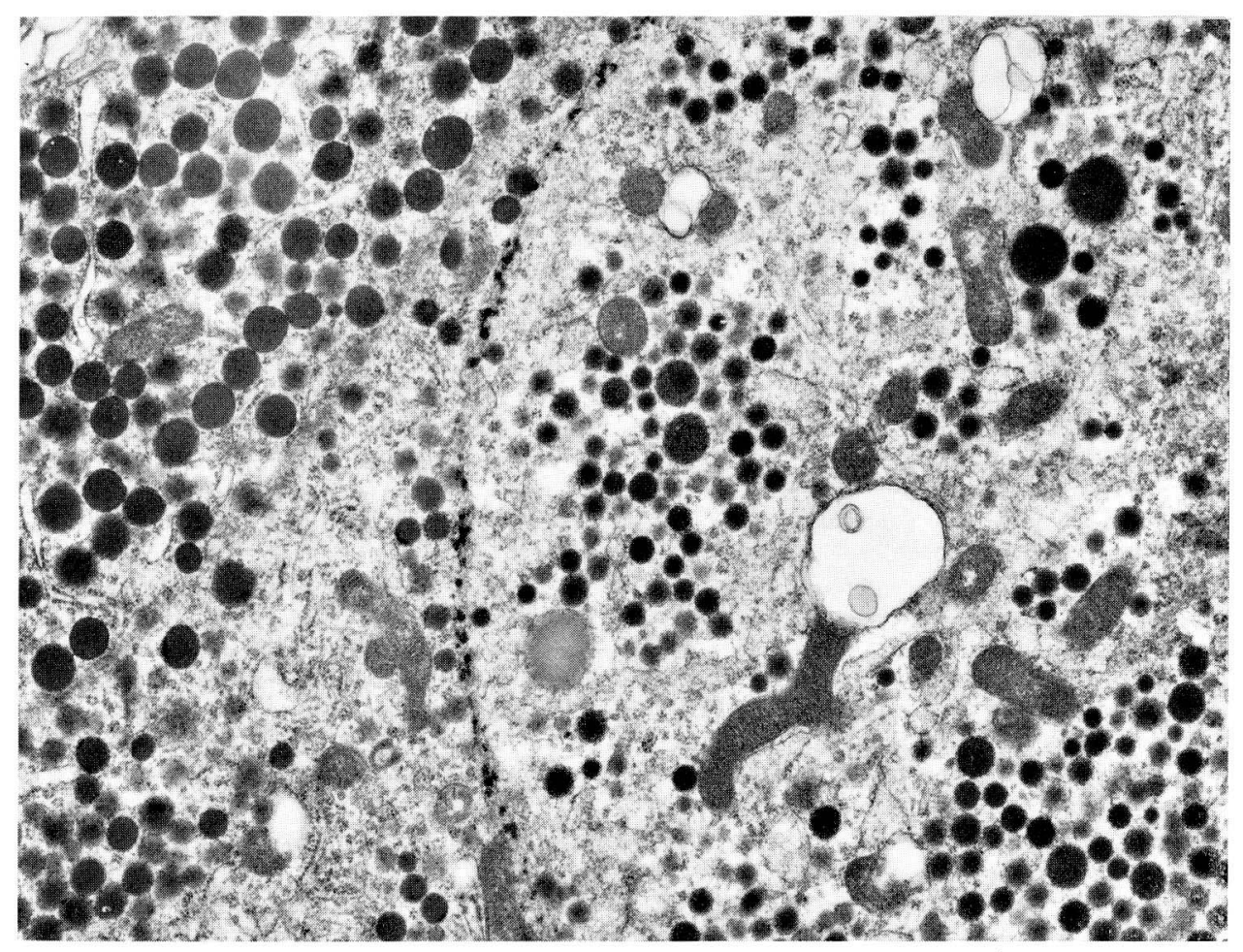

Fig. 4. Adenylate cyclase activity on an LH-gonadotroph in normal rat pituitary. The reaction is seen on the plasma membrane as a dotted line. It is negative on the secration granules and mitochondria. $\times 14,000$

given $1 \mathrm{ml}$ of solvent saline. They were sacrificed at 5, 10, 30, and $60 \mathrm{~min}$ after the treatment, and the excised tissues were fixed by perfusion with $2.5 \%$ glutaraldehyde in a $0.05 \mathrm{M}$ cacodylate buffer. After perfusion, $40 \mu$ sections of the anterior pituitary were prepared, and acid phosphatase (Gomori, 1950) and adenylate cyclase (WAGNER et al., 1972) were demonstrated light and electron microscopically (CAulfield, 1957; Luft, 1961).

\section{RESULTS}

\section{Electron microscopy of normal gonadotroph}

The FSH-gonadotrophs were found to be relatively large oval cells containing an anastomotic endoplasmic reticulum, well developed Golgi complexes, and secretory granules of about $250 \mathrm{~nm}$ in diameter (Fig. 1). The LH-gonadotrophs were relatively smaller oval cells containing a rather poor endoplasmic reticulum, large Golgi apparatuses, and two kinds of secretory granules, one of which measured about $250 \mathrm{~nm}$ and the other measured about $700 \mathrm{~nm}$ in diameter (Fig. 2). The FSH-gonadotrophs were more frequently encountered in mature males.

Fig. 5. LH-gonadotroph $5 \mathrm{~min}$ after the injection of LH-RH. The large granules have decreased remarkably and the cell now resembles an FSH-gonadotroph. $\quad \times 5,400$

Fig. 6. Adenylate cyclase activity demonstrated on an LH-gonadotroph, 5 min after the injection of LH-RH. Adenylate cyclase activity is clearly seen on the plasma membrane as a continuous black line. $\quad \times 17,000$ 


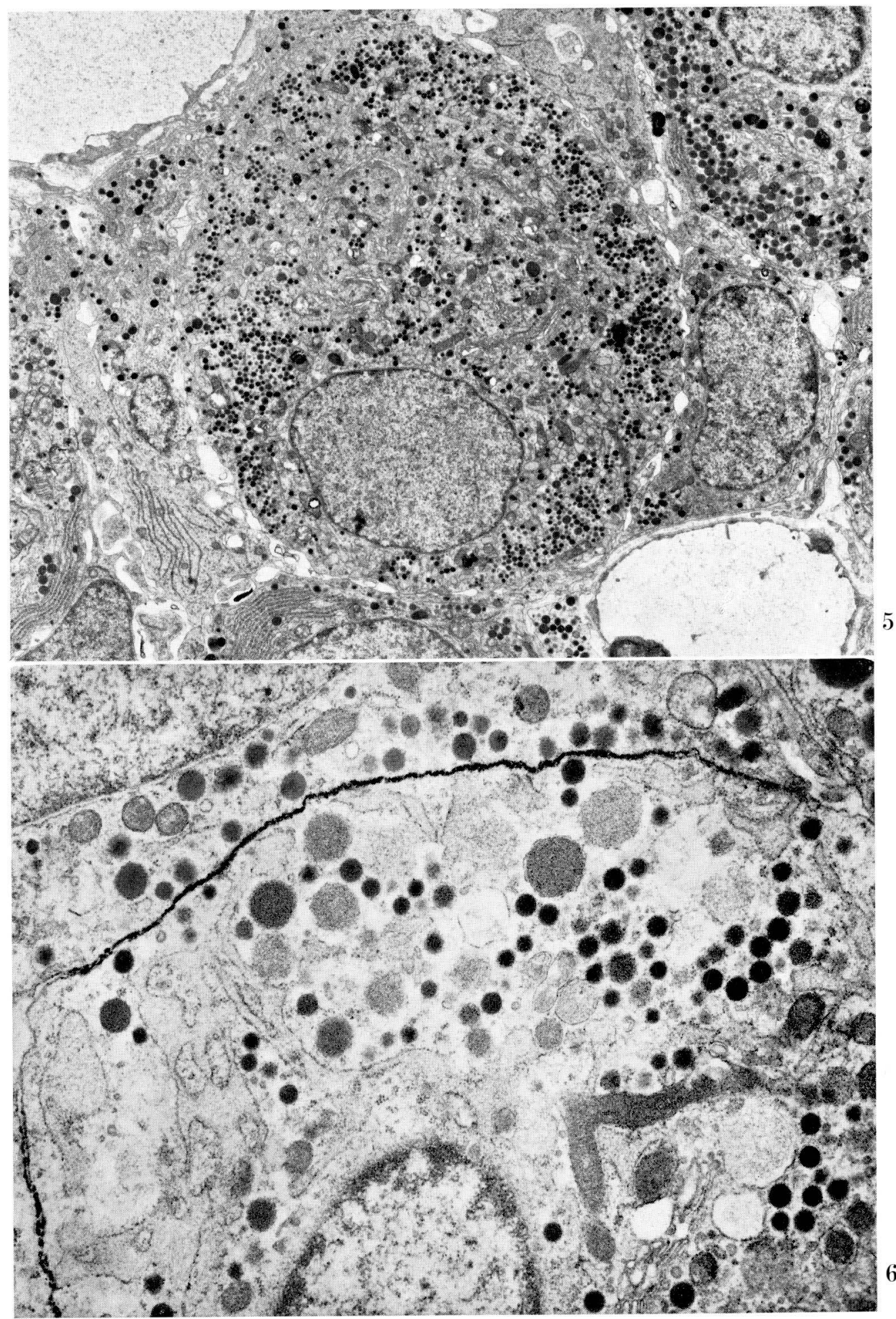

Fig. 5 and 6 . Legends on the opposite page. 


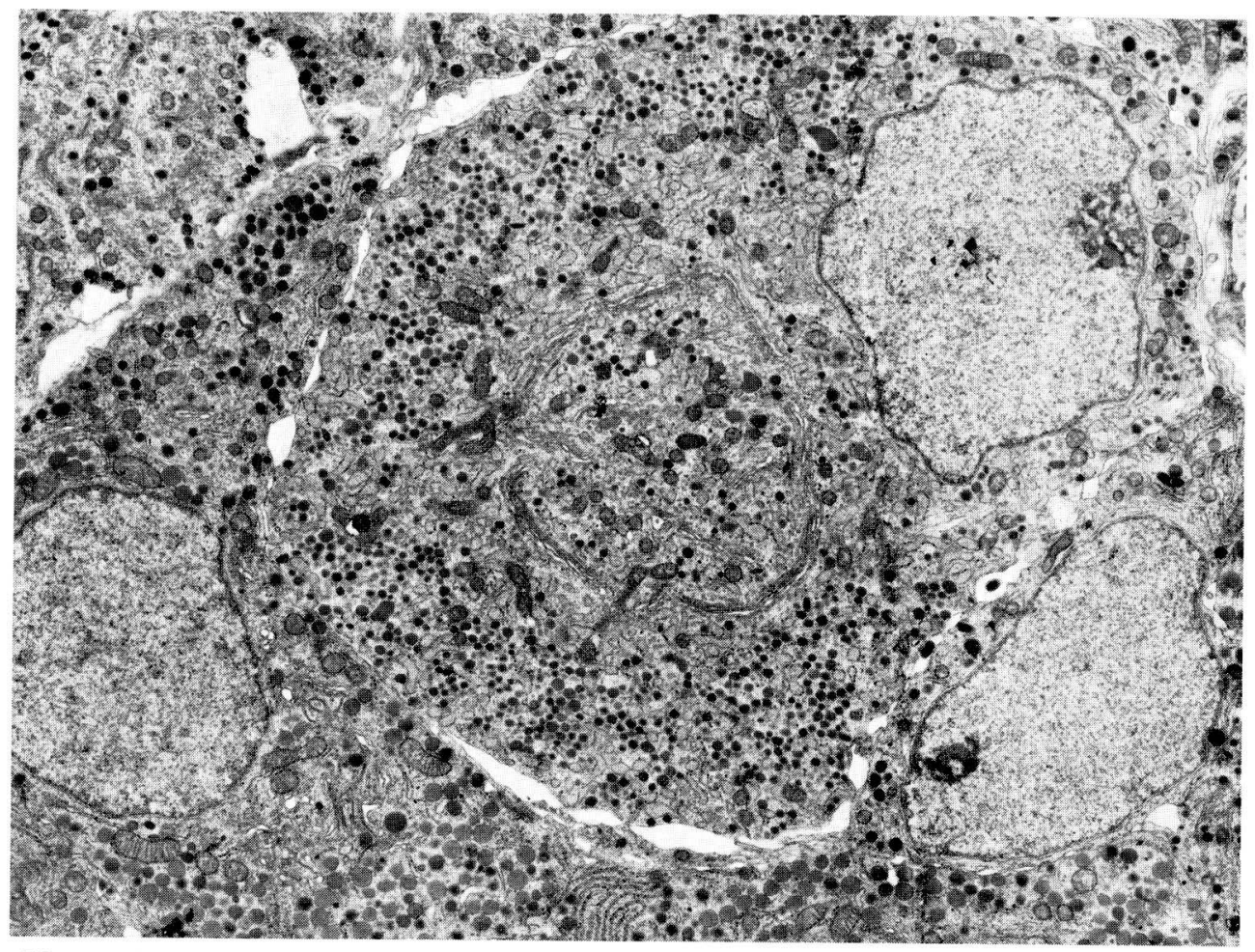

Fig. 7. Gonadotroph $10 \mathrm{~min}$ after LH-RH injection. Most secretion granules in the cell are the small type. Well developed Golgi apparatuses are seen in the center of the picture. $\times 6,600$

\section{Histochemistry of normal gonadotroph}

It was difficult to distinguish secretory granules from lysosomes in LH-gonadotrophs on electron micrographs. However, acid phosphatase, a marker enzyme for lysosomes, clearly showed positive so as to distinguish the lysosomes from the large secretion granules (Fig. 3).

Adenylate cyclase activity in the normal pituitary showed positive reaction products on the plasma membrane of the LH-gonadotrophs (Fig. 4). The enzyme activity was less remarkable on the FSH-gonadotrophs.

\section{Gonadotrophs after LH-RH treatment}

Five min after the LH-RH injection, the larger granules decreased drastically in the LH-gonadotroph and the cytoplasm was mostly occupied by the smaller granules. The cisternal spaces of the endoplasmic reticulum became dilated and anastomosis was frequently observed. Well developed Golgi apparatuses in circular arrangement were seen in the cytoplasm. After the LH-RH treatment, the LH-gonadotrophs came to resemble the FSH-gonadotrophs (Fig. 5); at 10 min, the large granules had substantially disappeared and almost all the granules occupying the cytoplasm were of the small type (Fig. 7).

Adenylate cyclase activity at 5 min through 10 min after the LH-RH treatment showed a clear increase and kept its high level as a dense black line on the plasma membrane (Fig. 6, 8).

At 30 min after LH-RH injection, the LH-gonadotrophs contained large amounts of 


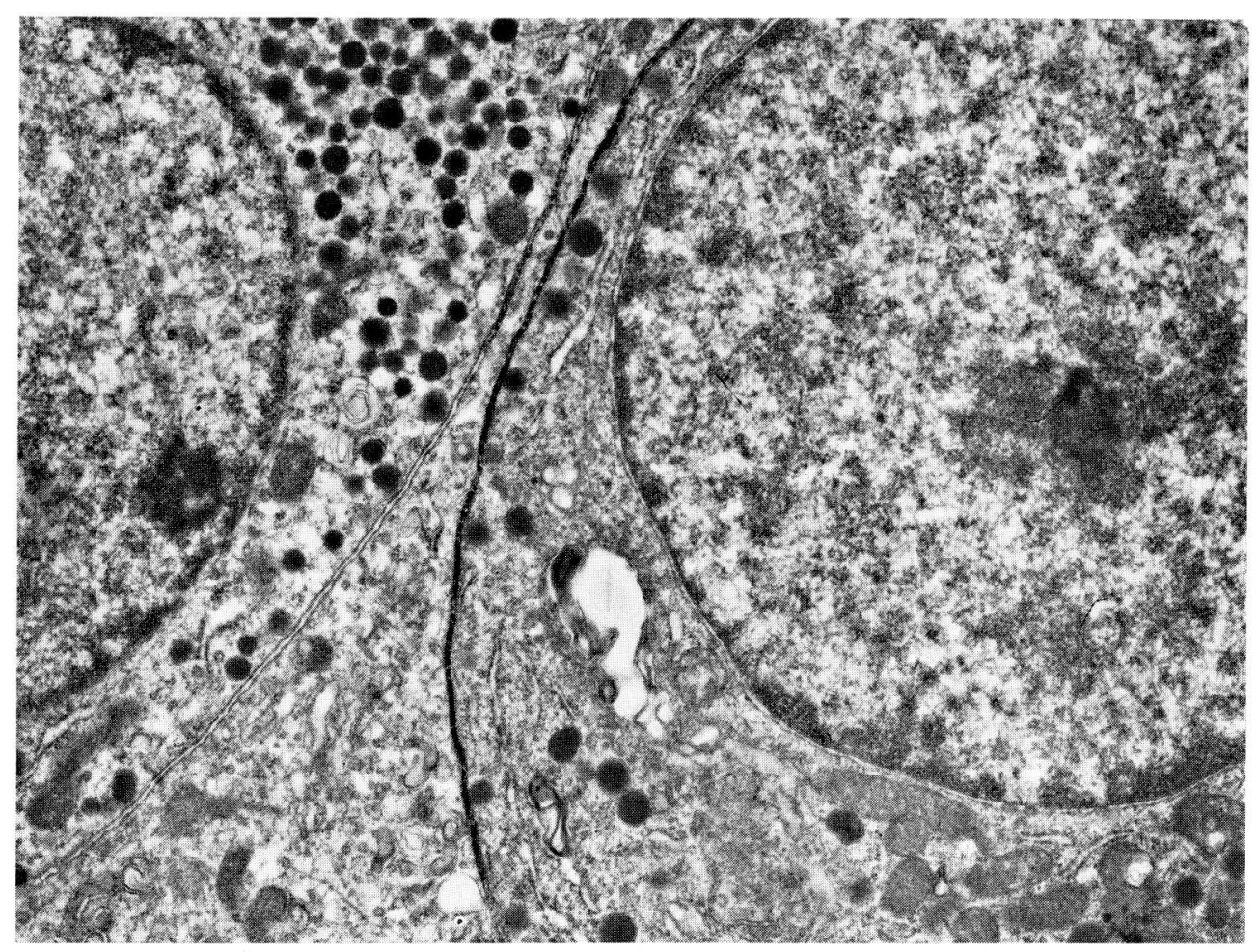

Fig. 8. Adenylate cyclase activity demonstrated in the pituitary cells 10 min after LH-RH injection. It is still clearly seen on the plasma membrane at as high a level as it was 5 min after the injection. $\times 15,000$

dilated endoplasmic reticulum. At this stage, the features of many of the LH-gonadotrophs were quite simillar to those of the FSH-gonadotrophs (Fig. 9); and adenylate cyclase activity decreased to normal levels (Fig. 10).

At $60 \mathrm{~min}$ after the LH-RH injection, both the small and large types of granules decreased in number, the remaining granules being of the smaller type scattered throughout the dilated endoplasmic reticulum (Fig. 11).

\section{DISCUSSION}

The single injection of LH-RH in the male rat induced a drastic discharge in the large secretion granules from the LH-gonadotrophs, and a transformation of these gonadotrophs to FSH-like gonadotrophs, concomitant with the enlargement of the cisternae of the endoplasmic reticulum, was seen. These morphological changes were remarkable from 5 to $30 \mathrm{~min}$ aftar LH-RH injection.

SoJI et al. (1976) reported elevations in LH concentrations in the serum 3 times higher at $5 \mathrm{~min}$ in LH, followed by elevations in FSH, 1.5 time higher at $30 \mathrm{~min}$, after an LH-RH injection. Adjacent section studies by electron microscopy and immunohistochemistry showed that deposits of anti-LH and anti-FSH were mainly in the small granule areas (PurAnder et al., 1978). From these data it was concluded that both the LH and FSH were contained in the same small granules. However, the resolution 


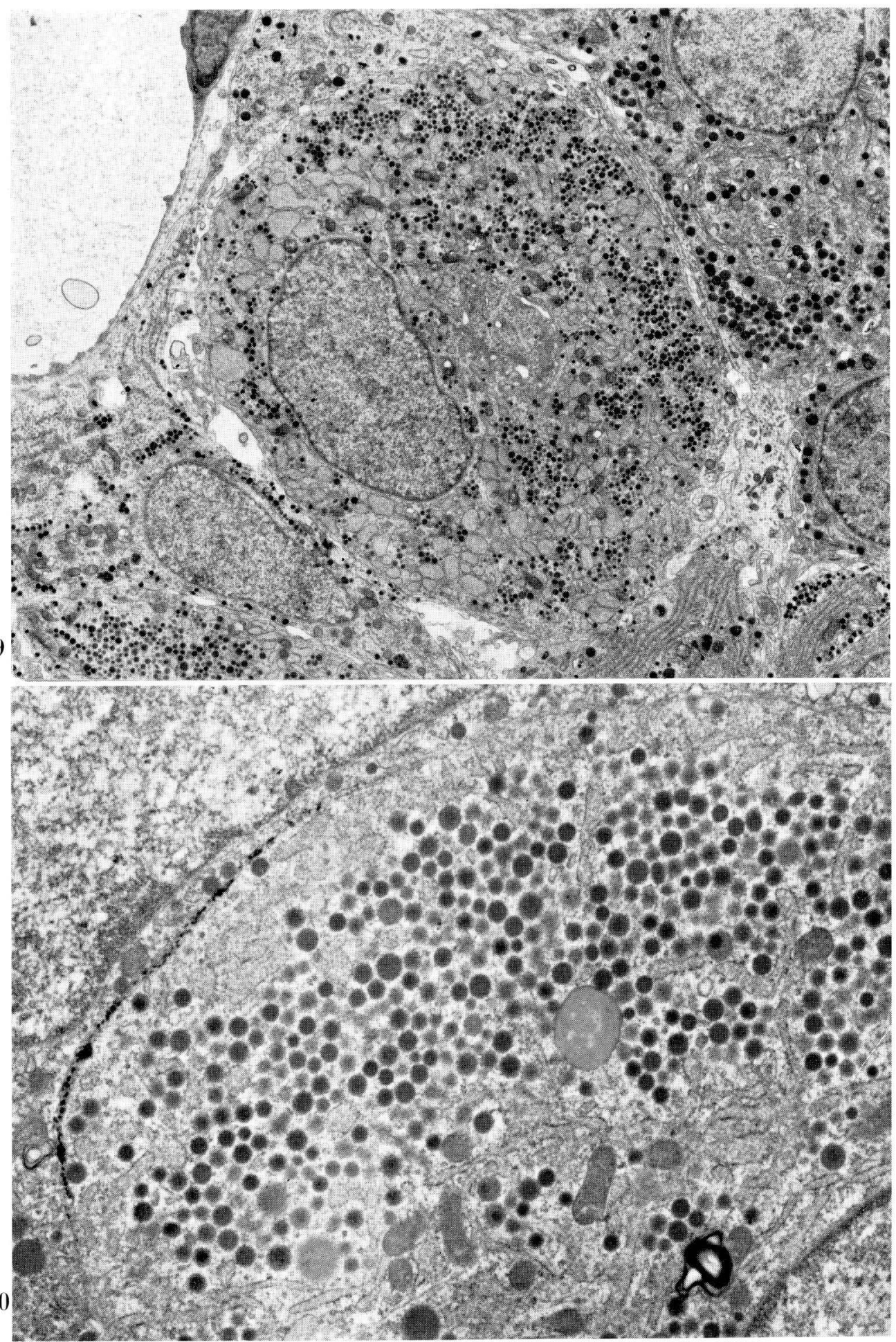

Fig. 9 and 10. Legends on the opposite page. 


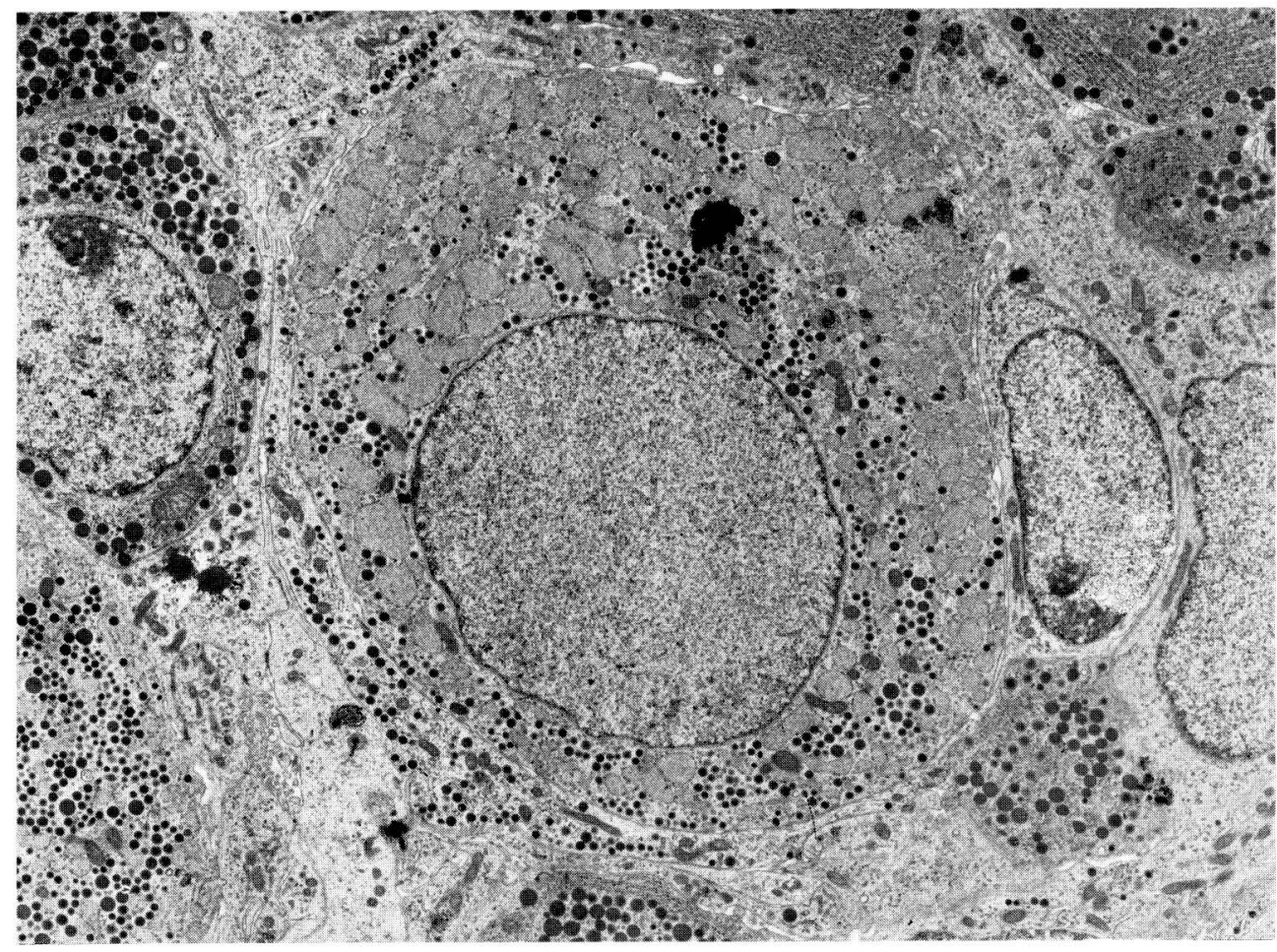

Fig. 11. Gonadotroph $60 \mathrm{~min}$ after LH-RH injection which has dilated endoplasmic reticulum as a castration cell dose. The decrease in the number of secretion granules of both types is conspicuous. $\times 6,900$

power of the light microscope was inadequate for distinguishing the small and large type granules. Moreover, if LH and FSH were contained in the same granules, it would be expected that the increases in LH and FSH should appear simultaneously, but a time gap between the increases in seral LH and FSH concentrations after LH-RH injection is evident. The adenylate cyclase activity on the plasma membrane of gonadotrophs rose when the large granules decreased in number. At the same time, a remarkable increase in seral LH was encountered. However, increases in seral FSH concentrations come later when a decrease in small granules takes place in the LHgonadotrophs. Therefore it is conceivable that the large granules which had decreased at 5 min after the LH-RH injection may have contained mainly $\mathrm{LH}$, and that the small granules which decreased at 30 min after the LH-RH injection contained mainly FSH.

Recently, Komuro and SHiod (1981) demonstrated adenylate cyclase in the anterior pituitary of male rats, its activity being localized on the plasma membrane of the somatotrophs and follicular cells, whereas no activity was found on the thyrotrophs or corticotrophs. According to them, most of the gonadotrophs showed little or no adenylate cyclase activity. It has been biochemically established (SponA, 1975; LABERIE et

Fig. 9. LH-gonadotroph in the pituitary $30 \mathrm{~min}$ after $\mathrm{LH}-\mathrm{RH}$ injection. Enlarged cisterns of endoplasmic reticulum are remarkable. Note the small type granules. $\times 5,400$

Fig. 10. Higher magnification of adenylate cyclase activity on a gonadotroph 30 min after LH-RH injection. The enzyme activity is still positive on the membrane, but it has decreased as compared with reaction $5-10 \mathrm{~min}$ after the injection. $\times 13,000$ 
al., 1975) that LH-RH activates adenylate cyclase activity and elevates cytoplasmic cyclic AMP. An increase in cAMP induces a discarge of LH into the serum. The histochemically shown activation in the present study of adenylate cyclase by LH-RH stands in good agreement with these findings. The reason for the discrepancy between the results on the enzyme activity in the gonadotrophs by Komuro and SHIODA and these by us may be due to the difference in animals used, in fixation procedure, and/or in incubation media.

The present study showed the possibility of the LH-gonadotroph losing its large secretion granules by LH-RH stimulation, and to change its morphology to that of the FSH gonadotroph. Our results strongly suggest that the LH and FSH-gonadotrophs belong to the same cell kind but to different stages of secretion process.

\section{REFERENCES}

Arimura, A., L. Debeljak and A. V. Schally: Stimulation of FSH release in vivo by prolonged infusion of synthetic LH-RH. Endocrinology 91: 529-532 (1972).

Bauman, R. and H. Kuhl : Effect of LH-RH and of a highly potent LH-RH along upon pituitary adenyl cyclase activity. Horm. Metab. Res. 12: 128-130 (1980).

Caulfield, J. B. : Effects of varying the vehicle for $\mathrm{OsO}_{4}$ in tissue fixation. J. Biophys. Biochem. 3: 827-833 (1957).

Debeljuk, L., A. Arimura, M. Shiino and E. G. Rennels : Effect of chronic treatment with LH/ FSH-RH in hypophisectomized pituitary-grafted male rats. Endoclinology 92: 921-930 (1973)

Farquhar, M. C., E. H. Skutensky and C. R. Hopkins: Structure and function of the anterior pituitary and dispersed pituitary. In: (ed. by) A. Tixier-Vidal and M. C. Farquhar: The anterior pituitary. Academic Press, New York, 1975 (p. 83-172).

Gomori, G.: Improved histochemical technic for acid phosphatase. Stain Technol. 25: 81-85 (1950).

Herbert, D. C.: Localozation of antisera to $\mathrm{LH} \beta$ and $\mathrm{FSH} \beta$ in the rat pituitary gland (1). Amer. J. Anat. 144: 379-385 (1975).

Komuro, M. and T. Shioda: Cytochemical localization of adenylate cyclase in the rat anterior pituitary. Cell Tiss. Res. 218: 103-111 (1981).

Kurosumi, K.: Functional classification of cell types of the anterior pituitary gland accomplished by electron microscopy. Arch. histol. jap. 29: 329-362 (1968).

Kurosumi, K. and Y. Oota: Electron microscopy of two types of gonadotrophs in the anterior pituitary glands of persistant estrous and diestrous rats. Z. Zellforsch. 85: $34-46$ (1968).

Labrie, F., P. Borget, A. Lemay, S. Lemaire, N. Barden, J. Drouin, I. Lemaire, P. Jolicoeur and A. Belanger: Role of cyclic AMP in the action of hypothalamic regulatory hormones Adv. cyclic Nucleotide Res. 5: 787-801 (1975).

Luft, J. H.: Improvments in epoxy resin embedding methods. J. biophys. biochem. Cytol. 9: 409-414 (1961).

Mirecka, J. and G. F. Pease : Localization of FSH- and LH-produsing cells in the pig adenohypophsis by an immunohistochemical technique. Fol. histochem. cytochem. 9: 365-372 (1971).

Nakane, P. K.: Classifications of anterior pituitary cell type with immunoenzyme histologic. J. Histochem. Cytochem. 18: 9-20 (1970).

Phifer, R. F., A. R. Midgley and S. S. Spicer: Immunohistological and histologic evidence that follicle-stimulating hormone and luteinizing hormone are present in the same cell type in the human pars distalis. J. clin. Endocrinol. Metab. 36: 125-141 (1973).

Purandare, T., M. Ser and W. E. Stumpf : Immunohistochemical localization of FSH and LH in rat pituitary Mol. cell. Endocrinol. 10: 57-62 (1978).

Rennels, E. G., E. M. Bodganove, A. Arimura, M. Saito and A. V. Schally : Ultrastructural observations of rat pituitary gonadotrophs following injection of purified porcin LH-RH. 
Endocrinology 88: 1318-1326 (1971).

Robin, C., P. Leloux, L. Vanbaelst, J. Golstein, M. Herant and J. P. Pasteels : Immunohisto. chemical study of the human pituitary with antiluteinizing hormone, anti-follicle stimulating hormone and antithyrotrophin sera. Acta endocrinol. 72: 625-642 (1973).

Shiino, M. and E. G. Rennels : Ultrastructural observations of gonadotropin release in rats treated neonatally with testosteron. Texas Rep. Biol. Med. 31: 215-228 (1973).

Soji, T.: Changes of serum and pituitary TSH, LH and FSH concentrations following the slow infu. sion of TRH and LRH. Endocriol. jap. 25: 231-236 (1978a)

: Cytological changes of the pituitary basophiles in rats slowly infused with LRH and TRH in combination. Endocrinol. jap. 25: 259-274 (1978b).

Soji, T, K. Taya, M. Igarashi and F. Yoshimura : Acut and subacut effect of LH-RH upon LH- and FSH-gonadotrophs in castrated female rats with short-term estrogen-progesteron pretreatment. Endocrinol. jap. 21: 407-428 (1974).

Soji, T., T. Yashiro and F. Yoshimura : TRH and LRH and their terget cells with special reference to secretory cycle of basophils. Gunma Symp. Endocrinol. 13: 237-259 (1976).

Spona, J.: LH-RH-sensitive adenilate cyclase in isolated plasma membranes of rat adenohypophyses. Endocrinol. exp. 9: 27-34 (1975).

Tougard, C., B. Kerdelhue, A. Tixier-Vidal and M. Jutsz: Light and electron microscopic localizing hormone and its two subunits in rat hypophysis using peroxidase-labeled antibody technique. J. Cell Biol. 58: 503-521 (1973).

Wagner, R. C., P. Kriener, R. J. Barrnett and M. W. Bitensky : Biochemical characterrization and cytochemical localization of catecholamine-sensitive adenylate cyclase in isolated capillary endothelium. Proc. Nat. Acad. Sci. USA 69: 3175-3179 (1972).

Yoshida, T., Y. Hattori, H. Hoshida and M. Suzuki : Further study on the effects of LH-RH in rat anterior pituitary. Tohoku. J. exp. Med. 120: 71-74 (1976).

兽 兩彊

テ814-01 福岡市城南区七隈 34

福岡大学医学部

第二解剖学教室
Dr. Tsuyoshi SoJi

Department of Anatomy

Fukuoka University School of Medicine

34 Nanakuma, Jonan-ku

Fukuoka, 814-01 Japan 